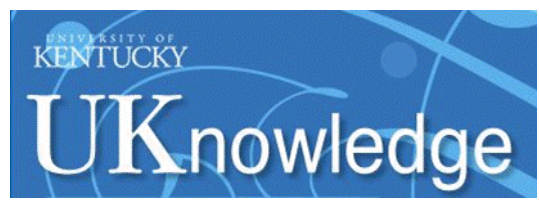

University of Kentucky

UKnowledge

7-2005

\title{
Fertilizer, Tillage, and Dairy Manure Contributions to Nitrate and Herbicide Leaching
}

\section{S. Stoddard}

University of California Cooperative Extension Service-Merced County

John H. Grove

University of Kentucky, jgrove@uky.edu

Mark S. Coyne

University of Kentucky, mark.coyne@uky.edu

William 0. Thom

University of Kentucky, wthom@uky.edu

Follow this and additional works at: https://uknowledge.uky.edu/pss_facpub

Part of the Environmental Microbiology and Microbial Ecology Commons, and the Plant Sciences

Commons

Right click to open a feedback form in a new tab to let us know how this document benefits you.

\section{Repository Citation}

Stoddard, C. S.; Grove, John H.; Coyne, Mark S.; and Thom, William O., "Fertilizer, Tillage, and Dairy Manure Contributions to Nitrate and Herbicide Leaching" (2005). Plant and Soil Sciences Faculty Publications. 8. https://uknowledge.uky.edu/pss_facpub/8

This Article is brought to you for free and open access by the Plant and Soil Sciences at UKnowledge. It has been accepted for inclusion in Plant and Soil Sciences Faculty Publications by an authorized administrator of UKnowledge. For more information, please contact UKnowledge@lsv.uky.edu. 
Fertilizer, Tillage, and Dairy Manure Contributions to Nitrate and Herbicide Leaching

Digital Object Identifier (DOI)

http://dx.doi.org/10.2134/jeq2004.0226

Notes/Citation Information

Published in Journal of Environmental Quality, v. 34, no. 4, p. 1354-1362.

The copyright holder has granted the permission for posting the article here. 


\title{
Fertilizer, Tillage, and Dairy Manure Contributions to Nitrate and Herbicide Leaching
}

\author{
C. S. Stoddard, J. H. Grove,* M. S. Coyne, and W. O. Thom
}

\begin{abstract}
Few studies have examined the water quality impact of manure use in no-tillage systems. A lysimeter study in continuous corn (Zea mays L.) was performed on Maury silt loam (fine, mixed, semiactive, mesic Typic Paleudalf) to evaluate the effect(s) of tillage (no-till [NT] and chisel-disk $[C D])$, nitrogen fertilizer rate $\left(0\right.$ and $\left.168 \mathrm{~kg} \mathrm{~N} \mathrm{ha}^{-1}\right)$, and dairy manure application timing (none, spring, fall, or fall plus spring) on $\mathrm{NO}_{3}-\mathrm{N}$, atrazine (2-chloro-4-ethylamino-6-isopropylamino$s$-triazine), and alachlor [2-chloro-2'-6'-diethyl- $N$-(methoxymethyl) acetanilide] concentrations in leachate collected at a $90-\mathrm{cm}$ depth. Herbicides were highest immediately after application, declining to less than $4 \mu \mathrm{g} \mathrm{L}^{-1}$ in about two months. Manure and manure timing by tillage interactions had little effect on leachate herbicides; rather, the data suggest that macropores rapidly transmitted atrazine and alachlor through the soil. Tillage usually did not significantly affect leachate $\mathrm{NO}_{3}-\mathrm{N}$, but no-tillage tended to cause higher $\mathrm{NO}_{3}-\mathrm{N}$. Manuring caused higher $\mathrm{NO}_{3}-\mathrm{N}$ concentrations; spring manuring had more impact than fall, but fall manure contained about $78 \%$ of the $\mathbf{N}$ found in spring manure. Nitrate under spring "only fertilizer" treatment exceeded $10 \mathrm{mg} \mathrm{L}^{-1} 38 \%$ of the time, compared with $15 \%$ for spring only manure treatment. After three years, manured soil leachate $\mathrm{NO}_{3}-\mathrm{N}$ exceeded that for soil receiving only $\mathbf{N}$ fertilizer. Soil profile $(90 \mathrm{~cm}) \mathrm{NO}_{3}-\mathrm{N}$ after corn harvest exceeding $22 \mathrm{~kg} \mathrm{~N} \mathrm{ha}^{-1}$ was associ-

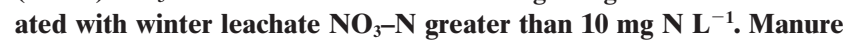
can be used effectively in conservation tillage systems on this and similar soils. Accounting for all $\mathrm{N}$ inputs, including previous manure applications, will be important.
\end{abstract}

$\mathrm{O}$ THE SHALLOW, well-drained, karst soils that occur in central Kentucky, no-till and other forms of conservation tillage are widely used. While the effects of tillage, nitrogen fertilizer, and manure on solute movement have been investigated, few studies have examined the combined effect of conservation tillage and manure use on subsurface water quality.

The combination of conservation tillage and manure may affect nitrogen and pesticide leaching through changes in soil structure and microbial dynamics. Considerable research shows that use of either no-tillage or manure can maintain or enhance soil structure (Blevins et al., 1983; Das and Chaudhri, 1981; Munyankusi et al., 1994). Well-structured soils (granular topsoil over blocky to subangular blocky subsoil) often exhibit macropore flow, which allows water percolation without appreciable wetting of the soil mass (Thomas and Phillips,

C.S. Stoddard, University of California Cooperative Extension Service-Merced County, 2145 Wardrobe Avenue, Merced, CA 953406496. J.H. Grove, M.S. Coyne, and W.O. Thom, Department of Plant and Soil Sciences, N-122 Agricultural Science-North, University of Kentucky, Lexington, KY 40546-0091. Mention of trade names is for information purposes only, and does not imply endorsement by the Kentucky Agricultural Experiment Station. Received 10 June 2004. *Corresponding author (jgrove@uky.edu).

Published in J. Environ. Qual. 34:1354-1362 (2005).

Technical Reports: Vadose Zone Processes and Chemical Transport doi:10.2134/jeq2004.0226

(c) ASA, CSSA, SSSA

677 S. Segoe Rd., Madison, WI 53711 USA
1979). One important consequence of macropore flow is that some of the salts on the soil surface will be moved to a greater depth by rain or irrigation than predicted by piston displacement theory.

Rainfall or irrigation received when the soil is at or near saturation can also provide substantial subsurface water recharge without substantial leaching of solutes (Thomas and Phillips, 1979). Edwards et al. (1992) observed that the first high intensity storm following chemical tracer application to dry soil resulted in both high water flow and high solute concentrations in macropores, whereas surface applied chemicals were transported less in subsequent high intensity storms. Low intensity storms caused little chemical transport because percolate volume was low.

The fate of surface applied herbicides depends on specific soil and climate factors and, in part, on the chemical properties of the herbicides. Kladivko et al. (1991) noted that small amounts of atrazine and alachlor were detected in drainage water within three weeks of pesticide application, after less than $2 \mathrm{~cm}$ of drainage from the soil. The chemicals arrived at the same time, in spite of their different equilibrium sorption coefficients. Thus, the timing of broadcast fertilizers, pesticides, and surface applied manure, in relation to rainfall events, is likely to affect solute concentrations of water moving through soils that exhibit macropore flow.

Nitrogen losses through leaching are an important water quality issue. Combined manure and fertilizer $\mathrm{N}$ additions are a significant source of excessive soil $\mathrm{NO}_{3}-\mathrm{N}$ (Jokela, 1992; Angle et al., 1993). However, the effects of independent manure and fertilizer $\mathrm{N}$ applications, each applied at agronomically optimum rates, are more variable. There is evidence that manure increases $\mathrm{NO}_{3}-\mathrm{N}$ leaching compared with fertilizer $\mathrm{N}$ applied at equivalent $\mathrm{N}$ rates (Roth and Fox, 1990; Jemison and Fox, 1994). This increase was attributed to late fall or early spring mineralization of organic $\mathrm{N}$, producing $\mathrm{NO}_{3}-\mathrm{N}$ during periods without crop uptake. Alternatively, some studies show that manure reduces $\mathrm{NO}_{3}-\mathrm{N}$ leaching compared with equivalent $\mathrm{N}$ rates from fertilizer (Sims, 1987; Jokela, 1992). The additional organic $C$ from manure may increase denitrification and macropore flow, or $\mathrm{N}$ mineralization rates may be synchronized with $\mathrm{N}$ uptake by the crop (Ma et al., 1999). Volatilization losses of $\mathrm{N}$ from manure are also especially important in NT systems (Sims, 1987; Eghball and Power, 1999).

Tillage affects $\mathrm{N}$ use efficiency and the subsequent leaching potential of $\mathrm{NO}_{3}-\mathrm{N}$. Enhanced water infiltration in no-till soils (Tyler and Thomas, 1977; Shipitalo et al., 1994) creates a situation where $\mathrm{NO}_{3}-\mathrm{N}$ leaching is likely. Earlier studies have shown both higher and lower concentrations of $\mathrm{NO}_{3}-\mathrm{N}$ in leachate under no-till, as compared with moldboard-plowed systems (McMahon

Abbreviations: $\mathrm{CD}$, chisel-disk tillage; NT, no-till. 
and Thomas, 1976; Tyler and Thomas, 1977; Angle et al., 1993).

As earlier reports have found both positive and negative effects on solute leaching due to $\mathrm{N}$ and/or tillage management choices, the intention of this study was to examine important combinations of these choices on a soil with physical properties typical of the well-drained soils formed in and over karstic limestone in the region. Thus, the objectives were to evaluate the effects of dairy manure application and application timing, choice of conservation tillage system, and fertilizer $\mathrm{N}$ on water, nitrate, atrazine, and alachlor transport through a shallow, well-drained karst soil.

\section{MATERIALS AND METHODS}

\section{Study Site and Experiment Design}

This experiment was established in fall 1991 at the Kentucky Agricultural Experiment Station Farm ( $38^{\circ} 07^{\prime}$ N, 84 $29^{\prime}$ W) near Lexington, $\mathrm{KY}$, to examine the nitrogen $(\mathrm{N})$ response of continuous corn and vadose-zone water quality as related to dairy (Bos taurus) manure application, tillage, and fertilizer $\mathrm{N}$ rate. Only the water quality data with respect to nitrate and herbicide application are reported here. The soil is classified as Maury silt loam, a well-drained soil formed in thin loess over residuum of phosphatic Ordovician limestone. Soil in the B horizon where lysimeters were installed (90-cm depth) exhibits subangular blocky structure. The depth to bedrock ranges from as little as $152 \mathrm{~cm}$ to greater than $500 \mathrm{~cm}$, and permeability ranges from 5 to $15 \mathrm{~cm} \mathrm{~h}^{-1}$ (Blevins et al., 1990). The area had been in unamended (no fertilizer, manure, or herbicides) bluegrass (Poa pratensis L.) and fescue (Festuca arundinacea L.) sod for at least $10 \mathrm{yr}$ before initiating this experiment. The experimental area was first planted to corn in 1992.

The field experiment design was a split-plot laid out in three randomized blocks. Main plots were six manure timing-tillage treatments: (i) no-tillage (NT), no manure; (ii) NT, fall manure; (iii) NT, spring manure; (iv) NT, fall + spring manure; (v) chisel plowing plus secondary discing (CD), no-manure; and (vi) CD, spring manure. Subplot treatments were 0,84 , and $168 \mathrm{~kg} \mathrm{~N}^{-1}$ as commercial ammonium nitrate. Main plot size was $3.7 \mathrm{~m}$ wide (four rows) by $27.3 \mathrm{~m}$ long. Subplots were randomly stacked, end-to-end, within main plots and were $3.7 \mathrm{~m}$ wide (four rows) by $9.1 \mathrm{~m}$ long. Main plots are laid out beside each other, so that crop rows were parallel throughout the field trial.

\section{Field Operations}

Fresh manure was surface applied with a small commercial spreader before planting for the spring manure treatments, and post harvest in early to mid-November for the fall manure treatments. The manure source was daily accumulation (20$35 \%$ solids) from the milking and loafing areas of a nearby dairy farm. Estimated available $\mathrm{N}$ rates from manure are shown in Table 1.

Tillage was initiated less than one hour after spring manure application. Tilled plots were chisel plowed to a depth of $25 \mathrm{~cm}$ and then disked twice. Corn cultivar Pioneer 3279 was planted at 57000 seed ha $\mathrm{h}^{-1}$ in $91-\mathrm{cm}$ rows with a ripple coulter no-till planter. Glyphosphate [isopropylamine salt of $\mathrm{N}$-(phosphonomethyl) glycine], 2,4-D (2,4-dichlorophenoxyacetic acid), atrazine, and alachlor were tank-mixed with a nonionic surfactant and applied at planting for weed control. Herbicide application dates were 1 May, 21 May, 11 May, and 10 May for 1992, 1993, 1994, and 1995, respectively. No herbicide was applied in the spring of 1996. Atrazine and alachlor were applied at
Table 1. Manure application rate, nutrient analysis, and estimated available $\mathbf{N}$ for each application event.

\begin{tabular}{|c|c|c|c|c|c|}
\hline Season applied & Manure rate & $\mathbf{N}$ & $\mathbf{P}$ & $\mathbf{K}$ & Available $\mathbf{N}+$ \\
\hline & Mg dry matter ha ${ }^{-1}$ & $\longrightarrow$ & $g_{\mathbf{~ k g}}^{-1}$ & 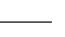 & $\mathbf{k g ~ h a}^{-1}$ \\
\hline Spring 1993 & 20.9 & 21.1 & 5.7 & 29.4 & 220 \\
\hline Fall 1993 & 14.4 & 25.5 & 10.0 & 19.5 & 180 \\
\hline Spring 1994 & 17.4 & 26.1 & 8.8 & 22.8 & 220 \\
\hline Fall 1994 & 16.2 & 20.3 & 7.0 & 17.2 & 165 \\
\hline Spring 1995 & 19.1 & 23.6 & 14.5 & 26.1 & 225 \\
\hline Fall 1995 & 15.3 & 22.9 & 8.5 & 18.4 & 175 \\
\hline
\end{tabular}

$\dagger$ Estimated after assuming $\mathbf{5 0} \%$ availability in the first year.

1.7 and $2.8 \mathrm{~kg}$ a.i. $\mathrm{ha}^{-1}$, respectively, which are typical rates for soils and weeds in central Kentucky. Nitrogen fertilizer was top-dressed by hand broadcasting 5 to 6 weeks after planting. All non-treatment-related field operations traversed all plots, equalizing traffic effects.

\section{Lysimeter Description and Installation}

Tension-free "pan" lysimeters (Tyler and Thomas, 1977) were installed in 20 of 48 subplots within the field experiment in April 1993. Lysimeters were not installed in the $84 \mathrm{~kg}$ $\mathrm{ha}^{-1}$ subplots. The stainless-steel lysimeters measured 0.61 by $0.91 \mathrm{~m}$ and had a volume of approximately $85 \mathrm{~L}(150-\mathrm{mm}$ rain capacity). Lysimeters were placed at a depth of $90 \mathrm{~cm}$, midway between the center two corn rows (longest pan dimension perpendicular to the corn rows), and $1.8 \mathrm{~m}$ from the end of selected plots. The bottom of each pan was tapered to deliver collected leachate to one point, where a stainless steel pipe fitting and standing pipe were attached to permit water removal. For a description of lysimeter installation, see Stoddard et al. (1998).

One lysimeter was installed in each selected subplot. Sixteen of the twenty pans were dedicated to a $2 \times 2 \times 2 \times 2$ (presence or absence of spring manure by tillage by 0 or $168 \mathrm{~kg} \mathrm{~N}^{-1}$ by two replicates) trial. Eight of the twenty pans were used to monitor two replicates of the four manure timing NT-manure timing treatments (all at $0 \mathrm{~kg} \mathrm{~N} \mathrm{ha}^{-1}$ ). Data from four pans (NT, no manure and NT, spring manure; two replicates each) were used in both trials.

\section{Sampling and Analysis}

Soil sampling was performed before manure application in the spring and fall of each season (mid April and mid November) with a tractor-mounted hydraulic soil probe. Four cores (2.88-cm diameter), two between and two within the corn rows, were taken to a depth of $90 \mathrm{~cm}$. Cores were divided into 0 - to $15-, 15-$ to $30-, 30$ - to $60-$, and $60-$ to $90-\mathrm{cm}$ depth increments and then composited for each plot. Soil samples were air-dried, crushed to pass a 2-mm sieve, and analyzed for $\mathrm{KCl}$ extractable ( $10 \mathrm{~g}$ to $25 \mathrm{~mL}) \mathrm{NO}_{3}-\mathrm{N}$ using the GreissIlosvay method (Keeney and Nelson, 1982) and automated colorimetry.

Water samples were collected and volumes measured following each rain event sufficient to create leaching. Water sampling began 14 June 1993 (approximately one month after pan installation) and continued through to 30 May 1996. The soil was allowed to drain for 24 to $48 \mathrm{~h}$, and samples were collected using a hand-held plastic rotary pump. Before sample acquisition, the pump, tubing, and sample container were rinsed with deionized water, and then again with approximately $100 \mathrm{~mL}$ of leachate from the pan, which was discarded. Approximately $75-\mathrm{mL}$ samples were collected in glass bottles with Teflon lined caps. The pan was pumped dry and the total volume recorded. Leachate samples were refrigerated at $4^{\circ} \mathrm{C}$ and analyzed for $\mathrm{NO}_{3}-\mathrm{N}$ within two days.

Water sample $\mathrm{NO}_{3}-\mathrm{N}$ concentrations were determined with 
Table 2. Sampling periods established for measurement of precipitation and leachate analysis.

\begin{tabular}{|c|c|c|c|c|c|c|c|}
\hline Period & & Inclusive dates & $\begin{array}{l}\text { Rain } \\
\text { events }\end{array}$ & $\begin{array}{c}\text { Sampling } \\
\text { events }\end{array}$ & $\begin{array}{c}\text { Total } \\
\text { precipitation }\end{array}$ & $\begin{array}{l}\text { Maximum } \\
\text { rain event }\end{array}$ & $\begin{array}{c}\text { Average } \\
\text { rain event }\end{array}$ \\
\hline & & & & & & $-\mathbf{m m ~} \mathbf{H}_{2} \mathrm{O}$ & \\
\hline 1 & Spring 1993 & 15 April-30 June & 15 & 4 & 269 & 60 & $\mathbf{2 0} \pm 17$ \\
\hline 2 & Summer 1993 & 1 July-14 November & 25 & 4 & 467 & 87 & $17 \pm 21$ \\
\hline 3 & Fall 1993 & 15 November-31 December & 10 & 3 & 144 & 88 & $22 \pm 27$ \\
\hline 4 & Winter 1994 & 1 January-14 April & 20 & 6 & 427 & 63 & $20 \pm 21$ \\
\hline 5 & Spring 1994 & 15 April-30 June & 16 & 4 & 209 & 53 & $19 \pm 19$ \\
\hline 6 & Summer 1994 & 1 July-14 November & 21 & 3 & 343 & 68 & $15 \pm 15$ \\
\hline 7 & Fall 1994 & 15 November-31 December & 8 & 3 & 126 & 36 & $18 \pm 15$ \\
\hline 8 & Winter 1995 & 1 January-14 April & 21 & 5 & 255 & 57 & $11 \pm 16$ \\
\hline 9 & Spring 1995 & 15 April-30 June & 23 & 9 & 415 & 83 & $18 \pm 17$ \\
\hline 10 & Summer 1995 & 1 July-14 November & 27 & 5 & 383 & 50 & $14 \pm 14$ \\
\hline 11 & Fall 1995 & 15 November-31 December & 7 & 2 & 99 & 28 & $14 \pm 11$ \\
\hline 12 & Winter 1996 & 1 January-14 April & 21 & 7 & 243 & 50 & $12 \pm 13$ \\
\hline 13 & Spring 1996 & 15 April-May 9 & 16 & 4 & 196 & 69 & $12 \pm 17$ \\
\hline
\end{tabular}

$\dagger$ Mean plus or minus one standard deviation.

the Greiss-Ilosvay method (Keeney and Nelson, 1982), using automated colorimetry. Nitrite and ammonium $\mathrm{N}$ were not usually present and are not reported here. Flow-weighted $\mathrm{NO}_{3}-\mathrm{N}$ concentrations, defined as the sum of the amounts of $\mathrm{NO}_{3}-\mathrm{N}$ found in individual leaching events (event $\mathrm{NO}_{3}-\mathrm{N}$ concentration times event leachate volume) within a specified time period (discussed below), divided by the total leachate volume collected within that time period (Jemison and Fox, 1994), were calculated for each lysimeter pan. Atrazine and alachlor were detected by a competitive enzyme linked immunosorbent assay (ELISA) procedure (Agri-Diagnostics Associates, 1992) and measured with a microplate autoreader. Selected samples were also analyzed by gas chromatography-mass spectrometry, which yielded comparable results, so only the ELISA results are present here. Flow-weighted herbicide concentrations are reported as $\mu \mathrm{g} \mathrm{\textrm {L } ^ { - 1 }}$.

\section{Statistical Analysis}

Due to the seasonal nature of water flow and the timing of field operations (including soil sampling and manure, fertilizer, and herbicide applications), the water data were analyzed after subdividing the calendar year into seasonal periods, shown in Table 2. Grouping the data facilitated analysis and reduced the influence of individual events on variation. Analysis of variance in the lysimeter data was performed using the general linear models (GLM) procedure in the Statistical Analysis System Version 6.12 (SAS Institute, 1989). The data were separated to test the effects of spring manure, tillage, and $\mathrm{N}$ rate (16 pans), and the effect of manure application timing (8 pans). The least significant difference (LSD test) was used to determine whether treatment means were significantly different. Due to data variability (coefficients of variation frequently exceeded $100 \%$ ), treatment effects are discussed at the $p \leq 0.25$ level. This alpha level reduced the potential of making a Type II error, claiming a treatment effect was not different when in fact it was, but increased the chance for a Type I error, claiming a treatment effect was different when it really was not. Because this study investigated management practices that might degrade water quality, we felt that avoiding Type II error was more important. For a thorough discussion of the consequence of significance level selection on risk assessment and management decisions, see Carmer and Walker (1988).

\section{RESULTS AND DISCUSSION}

\section{Water Flow}

Pans were pumped 59 times, after rainfall of significant intensity or duration to cause flow (Table 2). Flow was subject to seasonal variation, with greater flow occurring in the winter and spring periods.

In the tillage by spring manure by fertilizer $\mathrm{N}$ trial, there was generally less leachate volume under manured, than under unmanured, soils. Significant reductions were found in 6 of 13 sampling periods (Table 3 ). Tillage rarely had a significant effect ( 2 of 13 periods), but leachate under $C D$ soil typically exceeded that of NT soil (Table 3 ). Fertilizer N rate, alone or in combination with other treatment factors, did not significantly affect leachate volumes in any period (data not shown).

Early in the NT-manure timing experiment (first sampling period) there was greater leachate under unmanured NT soil. This effect became less substantial with time, and, in the last eight periods, there was no discernable trend in the influence of manure application timing on the amount of leachate collected under NT soil.

Some reduction in water flow in manured soil may be attributed to surface crusting and sealing by the semisolid manure used in this study. Studies at the University of Kentucky have shown that water infiltration rates were significantly reduced after applying semisolid dairy manure to a well-structured soil, and a 24-h delay before rainfall significantly lowered the saturated infiltration rate compared with immediate rainfall (Bottom et al., 1986). This reduction in infiltration has been attributed to suspended organic particles clogging soil pores at the surface (Clanton and Slack, 1987; Barrington and Madramootoo, 1989). Dried organic matter can also be strongly hydrophobic (Edwards et al., 1989), thus limiting water entry into the soil matrix.

The somewhat increased leachate collection under CD soils may be due to crop residue remaining on the soil surface that prevents soil crusting and surface sealing. Reduced water infiltration in plowed soils is usually attributed to semi-impermeable surface crusts that form from raindrop impact (Freese et al., 1993). Because CD tillage stirred the soil without inverting it, soil conditions were conducive to water infiltration and subsequent drainage.

\section{Flow-Weighted Nitrate Nitrogen Concentrations}

Tillage had few statistically significant impacts on flowweighted $\mathrm{NO}_{3}-\mathrm{N}$ (4 of 13 sampling periods), though NT management often resulted in higher leachate $\mathrm{NO}_{3}-\mathrm{N}$ (Table 4). The lack of significant differences due to 
Table 3. Average leachate quantity as affected by spring manure and tillage, and by manure timing to no-till soil.

\begin{tabular}{|c|c|c|c|c|c|c|c|c|c|c|c|c|c|}
\hline \multirow[b]{3}{*}{ Treatment $\dagger$} & \multicolumn{13}{|c|}{ Period $\neq$} \\
\hline & \multicolumn{3}{|c|}{1993} & \multicolumn{4}{|c|}{1994} & \multicolumn{4}{|c|}{1995} & \multicolumn{2}{|c|}{1996} \\
\hline & 1 (Sp) & 2 (Su) & $3(\mathbf{F})$ & $4(W)$ & $5(\mathrm{Sp})$ & $6(\mathrm{Su})$ & $7(\mathbf{F})$ & $8(W)$ & 9 (Sp) & $10(\mathrm{Su})$ & $11(\mathbf{F})$ & $12(W)$ & 13 (Sp) \\
\hline \multicolumn{14}{|c|}{ Spring manure by tillage trial (averaged over fertilizer $\mathbf{N}$ treatments) } \\
\hline & & & & & & & cm of $n$ & & & & & & \\
\hline No manure & 3.8 & 3.2 & 13.0 & 23.0 & 8.1 & 0.2 & 2.0 & 11.3 & 16.2 & 0.9 & 1.2 & 8.8 & 20.3 \\
\hline Spring manure & 3.2 & 1.9 & 6.7 & 11.3 & 2.6 & 0.2 & 0.8 & 5.2 & 19.0 & 0.4 & 0.5 & 3.0 & 12.7 \\
\hline CD & 2.7 & 2.0 & 12.4 & 21.6 & 5.9 & 0.2 & 1.6 & 11.5 & 19.2 & 0.7 & 1.0 & 7.4 & 20.6 \\
\hline NT & 4.3 & 3.2 & 7.3 & 12.6 & 4.8 & 0.2 & 1.2 & 5.0 & 16.0 & 0.5 & 0.7 & 4.5 & 12.4 \\
\hline \multicolumn{14}{|c|}{$p$ value } \\
\hline Manure & NS & NS & NS & 0.17 & 0.24 & NS & 0.15 & 0.15 & NS & NS & 0.11 & NS & 0.20 \\
\hline Tillage & NS & NS & NS & NS & NS & NS & NS & 0.15 & NS & NS & NS & NS & 0.17 \\
\hline Manure $\times$ tillage & NS & NS & NS & NS & NS & NS & NS & NS & NS & NS & 0.17 & NS & NS \\
\hline CV, \% & 133.4 & 140.1 & 94.3 & 75.8 & 103.9 & 5.3 & 65.0 & 97.1 & 42.3 & 70.6 & 46.5 & 66.0 & 65.5 \\
\hline \multicolumn{14}{|c|}{ No-tillage soil manure timing trial } \\
\hline & & & & & & & cm of $\mathrm{v}$ & & & & & & \\
\hline No manure & 12.2 & 8.2 & 16.9 & 25.3 & 12.2 & 0.2 & 2.4 & 13.5 & 19.9 & 1.2 & 1.2 & 9.3 & 15.5 \\
\hline Spring & 2.8 & 3.2 & 9.7 & 19.2 & 4.2 & 0.1 & 1.4 & 4.5 & 18.1 & 0.4 & 1.2 & 6.1 & 15.0 \\
\hline Fall & 0.4 & 2.4 & 9.6 & 21.2 & 5.6 & 0.3 & 3.6 & 17.8 & 17.8 & 0.5 & 2.0 & 10.7 & 16.3 \\
\hline Fall + spring & 2.9 & 2.1 & 3.8 & 17.3 & 5.3 & 0.1 & 0.7 & 17.8 & 12.6 & 0.5 & 0.6 & 3.3 & 17.4 \\
\hline LSD (0.25) & 7.4 & NS & NS & NS & NS & 0.14 & NS & NS & NS & NS & NS & NS & NS \\
\hline CV, \% & 112 & 135 & 121 & 111 & 129 & 18 & 101 & 113 & 35 & 105 & 81 & 111 & 59 \\
\hline
\end{tabular}

$\dagger \mathrm{CD}=$ chisel/disk, NT = no-tillage.

$+\mathrm{Sp}=$ spring, $\mathbf{S u}=$ summer, $\mathbf{F}=$ fall, $\mathbf{W}=$ winter.

$\S$ Probability of observing an $F$ value at or above the sample test statistic. NS $=$ not significant at the $75 \%$ level of confidence.

tillage in this study may be because CD conservation tillage did not substantially disturb soil physical and microbial characteristics. Interactions between tillage and spring manuring or tillage and fertilizer $\mathrm{N}$ use were usually not significant, though when these were observed there were elevated leachate nitrate levels when either manure or $\mathrm{N}$ fertilizer were applied to NT soils. Elevated $\mathrm{NO}_{3}-\mathrm{N}$ concentrations in NT soils have been attributed to greater mineralization of the increased organic matter found there (Doran, 1980; Blevins et al. 1983), and increased macropore flow (McMahon and Thomas, 1976; Tyler and Thomas, 1977; Shipitalo and Edwards, 1993).

A significant increase in leachate $\mathrm{NO}_{3}-\mathrm{N}$ concentration due to $\mathrm{N}$ fertilizer application was observed in all sampling periods except 6 and 11, for which the CVs are large and the $\mathrm{NO}_{3}^{-}$increases negligible (Table 4). In 7 of the 13 water sampling periods, largely early in

Table 4. Flow-weighted leachate $\mathrm{NO}_{3}-\mathrm{N}$ as affected by spring manure, tillage and fertilizer $\mathrm{N}$, and by manure timing to no-till soil.

\begin{tabular}{|c|c|c|c|c|c|c|c|c|c|c|c|c|c|}
\hline \multirow[b]{3}{*}{ Treatment $\dagger$} & \multicolumn{13}{|c|}{ Period $\div$} \\
\hline & \multicolumn{3}{|c|}{1993} & \multicolumn{4}{|c|}{1994} & \multicolumn{4}{|c|}{1995} & \multicolumn{2}{|c|}{1996} \\
\hline & 1 (Sp) & 2 (Su) & $3(\mathbf{F})$ & $4(W)$ & 5 (Sp) & $6(\mathrm{Su})$ & 7 (F) & $8(W)$ & 9 (Sp) & $10(\mathrm{Su})$ & $11(\mathbf{F})$ & $12(W)$ & 13 (Sp) \\
\hline \multicolumn{14}{|c|}{ Spring manure by tillage by $N$ rate trial } \\
\hline & & & & & & & $\mathrm{g} \mathrm{NO}_{3}$ & $\mathbf{L}^{-1}$ & & & & & \\
\hline No manure & 3.9 & 2.8 & 6.6 & 7.7 & 3.1 & 2.1 & 3.3 & 11.7 & 2.2 & 2.2 & 5.3 & 12.3 & 7.8 \\
\hline Spring manure & 9.8 & 6.7 & 10.4 & 14.6 & 7.1 & 4.1 & 7.3 & 37.3 & 9.2 & 5.2 & 14.4 & 27.5 & 18.3 \\
\hline CD & 7.7 & 4.6 & 7.6 & 9.1 & 5.2 & 2.9 & 6.5 & 18.5 & 4.8 & 3.9 & 10.1 & 18.2 & 10.8 \\
\hline NT & 6.0 & 4.9 & 9.4 & 13.1 & 5.0 & 3.5 & 4.1 & 25.4 & 6.6 & 3.5 & 9.0 & 21.6 & 15.2 \\
\hline $\begin{array}{l}0 \mathrm{~kg} \mathrm{~N} \mathrm{ha} \mathrm{ha}^{-1} \\
168 \mathrm{~kg} \mathrm{~N} \mathrm{ha}^{-1}\end{array}$ & $\begin{array}{l}4.8 \\
8.9\end{array}$ & $\begin{array}{l}2.1 \\
7.3\end{array}$ & $\begin{array}{l}3.9 \\
13.1\end{array}$ & $\begin{array}{l}6.9 \\
15.3\end{array}$ & $\begin{array}{l}4.4 \\
5.8\end{array}$ & $\begin{array}{l}2.4 \\
3.8\end{array}$ & $\begin{array}{l}1.9 \\
8.7\end{array}$ & $\begin{array}{l}6.1 \\
37.9\end{array}$ & $\begin{array}{l}3.0 \\
8.4\end{array}$ & $\begin{array}{l}2.7 \\
4.7\end{array}$ & $\begin{array}{l}5.6 \\
13.0\end{array}$ & $\begin{array}{l}12.3 \\
27.5\end{array}$ & $\begin{array}{l}10.9 \\
15.2\end{array}$ \\
\hline & \multicolumn{13}{|c|}{$p$ value } \\
\hline Manure & 0.04 & 0.02 & 0.10 & 0.03 & 0.01 & 0.20 & 0.05 & 0.12 & 0.01 & 0.05 & 0.03 & 0.02 & 0.01 \\
\hline Tillage & NS & NS & NS & 0.10 & NS & NS & 0.13 & NS & 0.21 & NS & NS & NS & 0.04 \\
\hline$N$ rate & 0.04 & 0.01 & 0.01 & 0.04 & 0.19 & NS & 0.01 & 0.03 & 0.02 & 0.20 & NS & 0.01 & 0.15 \\
\hline Manure $\times$ tillage & NS & NS & NS & NS & 0.08 & NS & NS & NS & 0.25 & NS & NS & NS & 0.12 \\
\hline Manure $\times \mathbf{N}$ rate & 0.17 & 0.01 & 0.25 & NS & NS & 0.19 & 0.04 & 0.22 & 0.09 & NS & NS & NS & NS \\
\hline Tillage $\times \mathbf{N}$ rate & NS & NS & NS & NS & 0.20 & NS & 0.08 & NS & NS & NS & NS & NS & NS \\
\hline $\mathbf{C V}, \%$ & 41.3 & 31.2 & 27.6 & 49.8 & 35.1 & 73.9 & 40.6 & 85.9 & 54.2 & 72.0 & 80.3 & 28.6 & 37.1 \\
\hline \multicolumn{14}{|c|}{ No-tillage soil manure timing trial } \\
\hline & & & & & & & $\mathrm{g} \mathrm{NO}_{3}$ & $\mathbf{L}^{-1}$ & & & & & \\
\hline No manure & 2.4 & 2.4 & 4.4 & 6.1 & 3.2 & 3.3 & 2.1 & 3.8 & 1.6 & 1.5 & 4.5 & 7.1 & 7.1 \\
\hline Spring & 5.3 & 2.2 & 5.2 & 11.9 & 6.8 & 2.9 & 1.6 & 10.6 & 4.8 & 3.3 & 8.5 & 18.6 & 18.6 \\
\hline Fall & 10.2 & 1.7 & 4.4 & 9.7 & 5.4 & 2.7 & 3.0 & 7.3 & 3.3 & 3.7 & 6.5 & 10.9 & 10.8 \\
\hline Fall + spring & 12.7 & 5.2 & 5.8 & 14.9 & 10.4 & 4.9 & 9.9 & 21.5 & 12.4 & 6.4 & 16.3 & 25.6 & 15.4 \\
\hline LSD (0.25) & 2.9 & 0.8 & 0.8 & 4.7 & 2.5 & 0.5 & 2.9 & 5.5 & 4.1 & 1.5 & 5.2 & 6.8 & 4.6 \\
\hline CV, \% & 26.7 & 18.4 & 11.0 & 31.0 & 27.8 & 10.7 & 50.1 & 36.0 & 52.3 & 27.6 & 40.8 & 31.1 & 25.2 \\
\hline
\end{tabular}

$\dagger \mathrm{CD}=$ chisel/disk, NT $=$ no-tillage.

$+\mathrm{Sp}=$ spring, $\mathbf{S u}=$ summer, $\mathbf{F}=$ fall, $\mathbf{W}=$ winter

$\S$ Probability of observing an $F$ value at or above the sample test statistic. $N S=$ not significant at the $75 \%$ level of confidence. 
the three-year experimental period, there was also a significant spring manure by fertilizer $\mathrm{N}$ interaction on leachate $\mathrm{NO}_{3}-\mathrm{N}$. The interaction was synergistic and positive (data not shown). Later in the experiment, the effects of spring manuring and fertilizer $\mathrm{N}$ application were simply additive. The application of $168 \mathrm{~kg}$ fertilizer $\mathrm{N} \mathrm{ha}^{-1}$ plus spring manure resulted in flow-weighted leachate $\mathrm{NO}_{3}-\mathrm{N}$ concentrations exceeding the USEPA drinking water standard $\left(10 \mathrm{mg} \mathrm{NO}{ }_{3}-\mathrm{N} \mathrm{L}^{-1}\right)$ in 10 of 13 periods (Fig. 1). In $\mathrm{N}$ fertilized soils that did not receive spring manure, leachate reached or exceeded $10 \mathrm{mg} \mathrm{NO}{ }_{3}-\mathrm{N} \mathrm{L}^{-1}$ in 5 of 13 periods.

The significant increase in flow-weighted $\mathrm{NO}_{3}-\mathrm{N}$ observed in leachate under manured soils (Table 4) agrees with results of other agronomic studies using manure as an N source (Roth and Fox, 1990; Jokela, 1992; Angle et al., 1993; Jemison and Fox, 1994). The differences in $\mathrm{NO}_{3}-\mathrm{N}$ concentrations due to manure or fertilizer $\mathrm{N}$ application were greater in fall (Periods 3, 7, and 11) and winter (Periods 4, 8, and 12), the latter also often a season of greater leaching (Table 3). This suggests that organic $\mathrm{N}$ mineralization in spring manured plots occurred in excess of crop $\mathrm{N}$ uptake during summer and also in the fall when crop $\mathrm{N}$ uptake was minimal, leading to increased soil $\mathrm{NO}_{3}-\mathrm{N}$ and elevated leachate $\mathrm{NO}_{3}-\mathrm{N}$ concentrations during the winter period. MacDonald et al. (1989) showed that residual $\mathrm{N}$ in soil (from organic matter or unused fertilizers) in the fall of the year, following harvest, is a potential source of $\mathrm{NO}_{3}-\mathrm{N}$ in ground water. Thus, when available $\mathrm{N}$ from fertilizer and/or mineralization of $\mathrm{N}$ from manure applications exceeded crop requirements, $\mathrm{NO}_{3}-\mathrm{N}$ concentrations in the leachate increased significantly. These data highlight the importance of accounting for all $\mathrm{N}$ inputs.

Significant differences in leachate $\mathrm{NO}_{3}-\mathrm{N}$ due to the timing of manure application to NT soils were observed in most periods (Table 4). Generally, fall manured had higher flow-weighted $\mathrm{NO}_{3}-\mathrm{N}$ than the unmanured soils in the spring of each year (Periods 1, 5, 9, and 13). Spring manuring generally caused higher $\mathrm{NO}_{3}-\mathrm{N}$ con- centrations in winter leaching periods (i.e., Periods 4, 8 , and 12). The fall plus spring manure treatment usually resulted in the highest leachate $\mathrm{NO}_{3}-\mathrm{N}$ concentrations, exceeding the USEPA drinking water standard in 8 of 13 periods.

Long-term studies and simulation models show that increased $\mathrm{NO}_{3}-\mathrm{N}$ leaching due to annual manuring occurs, relative to unmanured soils, because of the gradual buildup of mineralizable $\mathrm{N}$ in manured soils and the loss of soil organic matter in unmanured soils (Roth and Fox, 1990; Pang and Letey, 2000). This occurred in this trial, especially with the fall plus spring manure application (Fig. 2). There was a general temporal increase in flow-weighted leachate $\mathrm{NO}_{3}-\mathrm{N}$ concentration where either spring or fall plus spring manuring was done on an annual basis. Using a multiyear simulation model, Pang and Letey (2000) predicted increased N leaching from annual manuring, and attributed this to increasing residual organic $\mathrm{N}$. Organic $\mathrm{N}$ that is not mineralized in the first year contributes to a cumulative organic $\mathrm{N}$ pool that raises future nitrogen availability.

The total $\mathrm{NO}_{3}-\mathrm{N}$ in the soil profile after corn harvest has been suggested as a predictor of subsequent leachate $\mathrm{NO}_{3}-\mathrm{N} \mathrm{L}^{-1}$ concentrations (Jemison and Fox, 1994). We observed a significant $(p<0.01)$ linear relationship between the total mass of $\mathrm{NO}_{3}-\mathrm{N}$ in the $90-\mathrm{cm}$ soil profile, sampled after harvest in both 1993 and 1994, and the overwinter (November through April) flowweighted $\mathrm{NO}_{3}-\mathrm{N}$ concentration (Fig. 3). Soil samples were not taken in the fall of 1995. From this relationship, leachate concentrations will exceed $10 \mathrm{mg} \mathrm{NO}{ }_{3}-\mathrm{N} \mathrm{L}^{-1}$ if the upper $90 \mathrm{~cm}$ of the fall soil profile contains more than $22 \mathrm{~kg} \mathrm{NO}_{3}-\mathrm{N} \mathrm{ha}^{-1}$. These results compare favorably with other studies that have shown that when fall soil $\mathrm{NO}_{3}-\mathrm{N}$ approaches $25 \mathrm{~kg} \mathrm{ha}^{-1}$, significant amounts of $\mathrm{NO}_{3}^{-}$leach below the crop root zone (Roth and Fox, 1990; Angle et al., 1993; Jemison and Fox, 1994).

A weak relationship was found between soil profile $(90 \mathrm{~cm}) \mathrm{NO}_{3}-\mathrm{N}$, sampled in the spring before corn establishment, and the summer growing season (Periods 1,

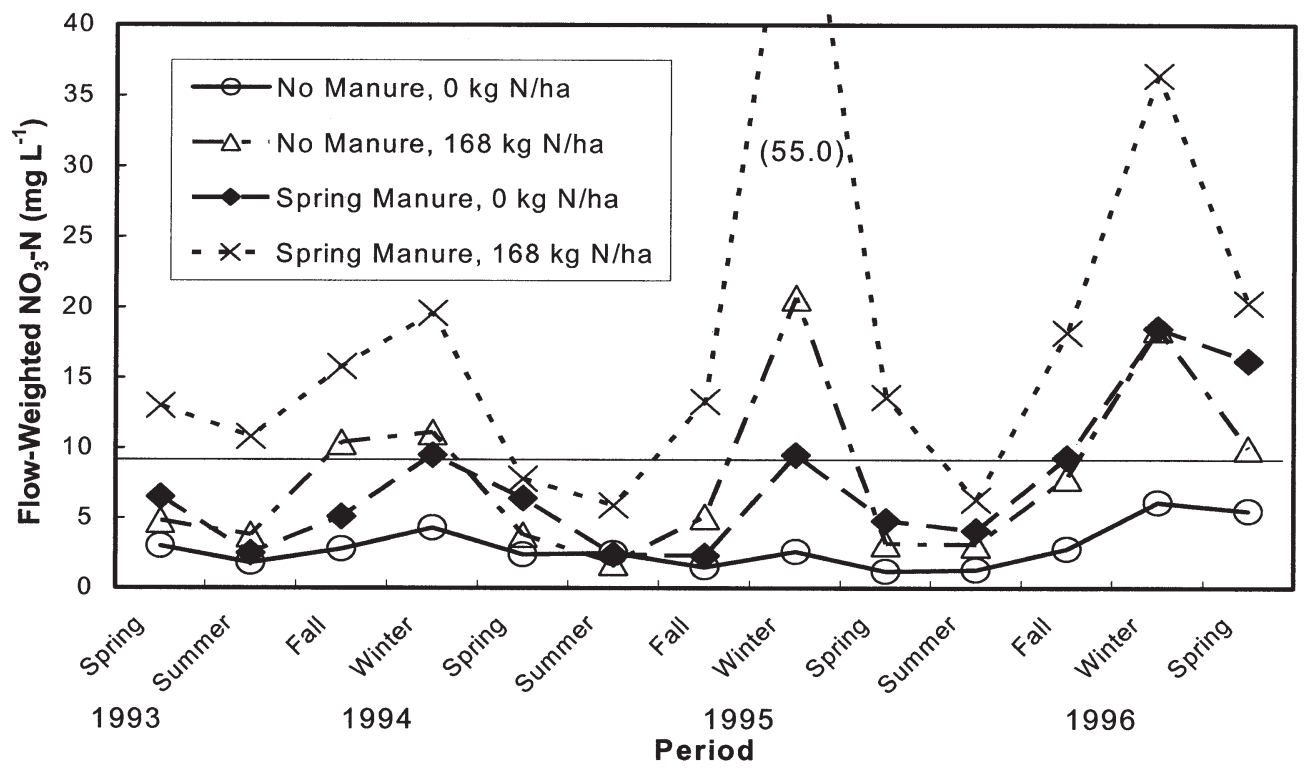

Fig. 1. Flow-weighted leachate $\mathrm{NO}_{3}-\mathrm{N}$, by seasonal period, as affected by spring manuring and fertilizer $\mathrm{N}$ applications, averaged across the two tillage systems. The horizontal line at $10 \mathrm{mg} \mathrm{NO}-\mathrm{N}_{3}^{-1}$ is the USEPA drinking water standard. 


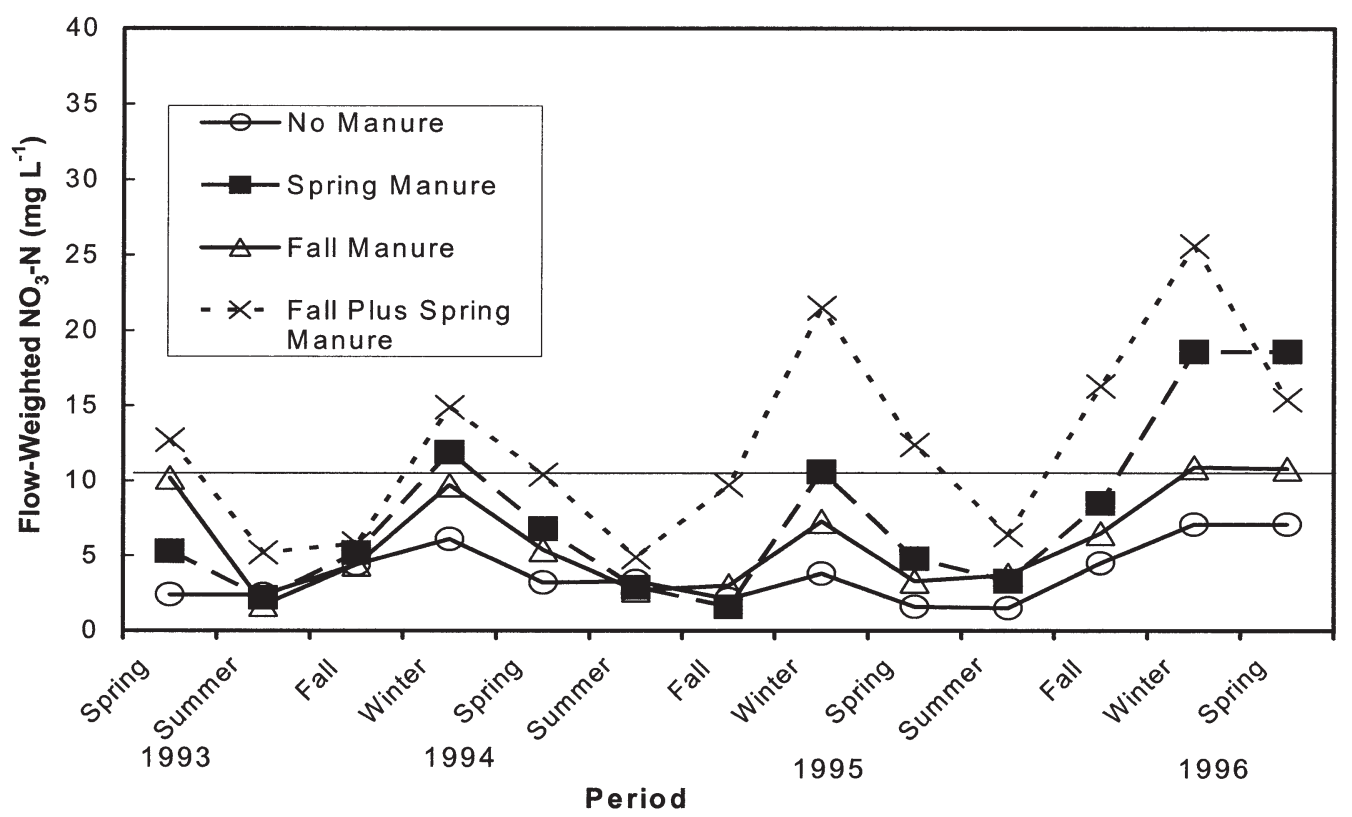

Fig. 2. Flow-weighted leachate $\mathrm{NO}_{3}-\mathrm{N}$, by seasonal period, as affected by the timing of manure application to no-tillage soil. The horizontal line at $10 \mathrm{mg} \mathrm{NO}-\mathrm{N}_{3}^{-1}$ is the USEPA drinking water standard.

2, 5, and 6) flow-weighted leachate $\mathrm{NO}_{3}-\mathrm{N}$ (data not shown). Unlike overwinter leachate, growing season leachate $\mathrm{NO}_{3}-\mathrm{N}$ rarely exceeded $10 \mathrm{mg} \mathrm{L}{ }^{-1}$, probably because of $\mathrm{N}$ uptake by corn.

Adams et al. (1994) suggested that manure should be applied in late spring or early summer, when crops and microorganisms are rapidly taking up $\mathrm{N}$, to minimize winter $\mathrm{NO}_{3}-\mathrm{N}$ leaching to ground water. Our study, however, found that late fall manure application did not significantly increase winter $\mathrm{NO}_{3}-\mathrm{N}$ leaching concentrations in comparison with a spring application (Table 4). Leachate $\mathrm{NO}_{3}-\mathrm{N}$ in the winter periods (i.e., Periods 4, 8 , and 12) after only fall manuring was generally less than that after only spring manuring. This observation is, in part, because we inadvertently added less manure $\mathrm{N}$ in our fall manuring (Table 1) and also, in part, because manure $\mathrm{N}$ mineralization was likely reduced by cooling temperatures after a late fall manure application. Fall manure typically contains more bedding material and less feces and urine because in late summer and fall the animals stayed out on pastures more and spent less time in and around milking and loafing areas from where the manure was recovered.

\section{Flow-Adjusted Herbicide Concentrations}

Almost all atrazine and alachlor concentrations greater than $1 \mu \mathrm{g} \mathrm{L}{ }^{-1}$ were found in spring samples taken soon

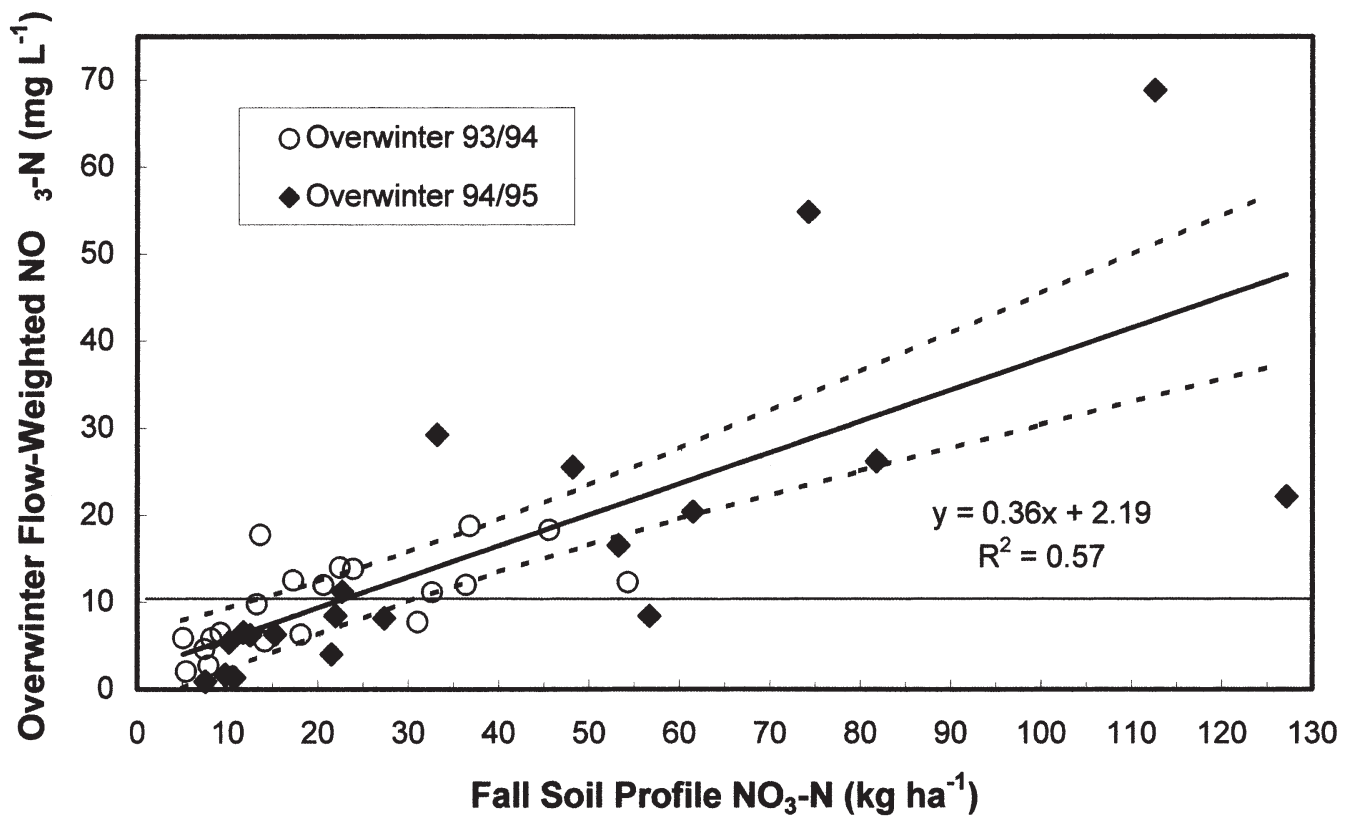

Fig. 3. Relationship between fall (after harvest) soil profile $(90 \mathrm{~cm})$ nitrate to overwinter (November-April) flow-weighted leachate $\mathrm{NO}_{3}-\mathrm{N}$ concentration. Dashed lines represent $95 \%$ confidence limits. The horizontal line at $10 \mathrm{mg} \mathrm{NO}{ }_{3}-\mathrm{N} \mathrm{L}^{-1}$ is the USEPA drinking water standard. 


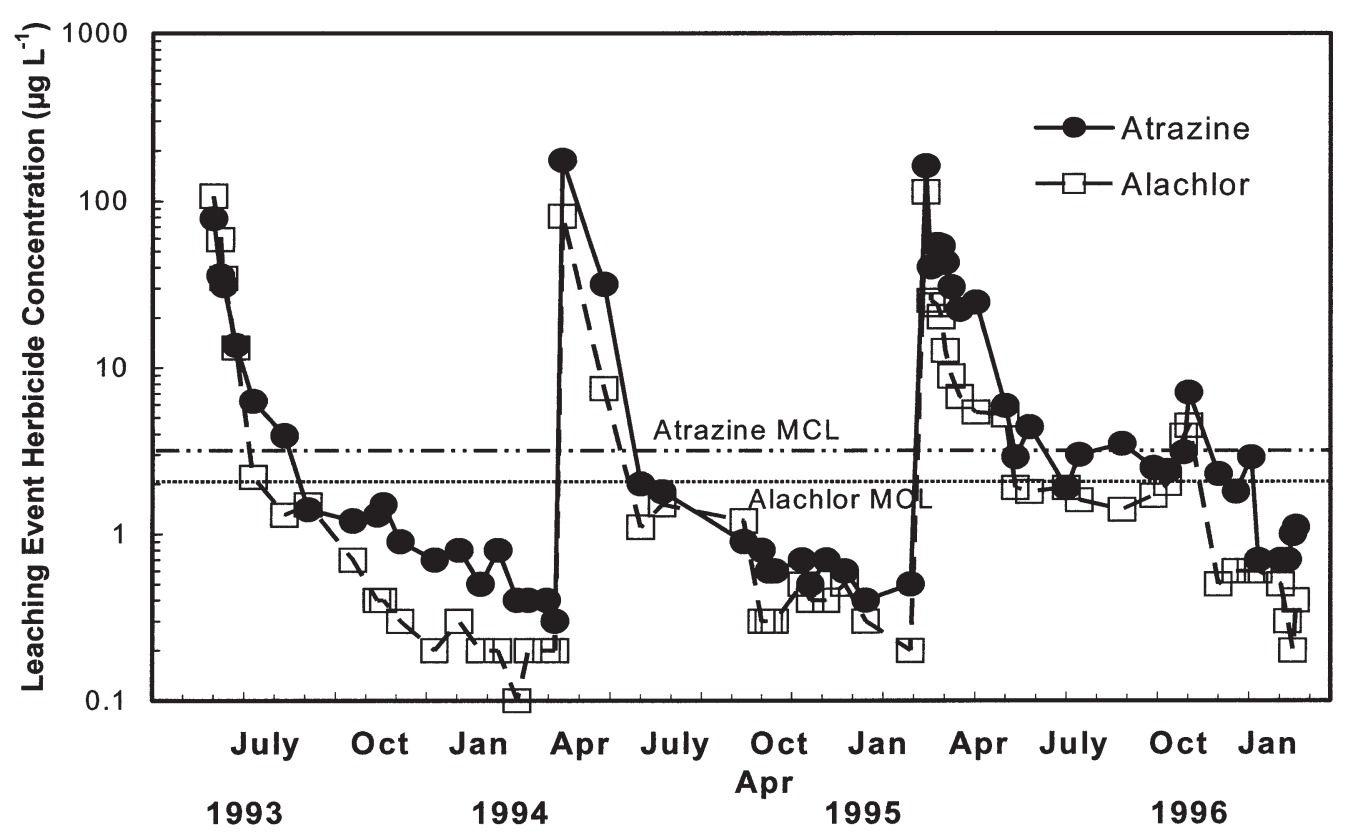

Fig. 4. Event average leachate atrazine and alachlor concentrations. Horizontal lines at 2 and $3 \mu \mathrm{g}$ herbicide $\mathrm{L}^{-1}$ are the alachlor and atrazine maximum contaminant levels (MCLs), respectively.

after herbicide application (Fig. 4). There were only a few events in the fall, winter, or early spring where herbicide concentrations above this level were found. In each year, the highest atrazine and alachlor concentrations appeared in leachate from the first event after herbicide application. Concentrations declined in subsequent samples, dropping below the USEPA maximum contaminant levels (MCLs) for atrazine and alachlor (3 and $2 \mu \mathrm{g} \mathrm{L}^{-1}$, respectively) in about two months. Except for the first two events after herbicide application in 1993, alachlor concentrations were lower, and declined faster, than did those for atrazine.

Average flow-adjusted atrazine and alachlor concentrations were greatest in the period of application (spring Periods 1, 5, and 9) of each year herbicides were applied (Tables 5 and 6), despite the lower volume of leachate collected at this time (Table 3). Herbicide concentrations were not higher in Period 13 because herbi- cides were not applied in 1996. This result, combined with the rapid arrival time in lysimeters, suggests that macropore flow occurred, rapidly transmitting the surface applied chemicals through the soil matrix, regardless of manure or tillage treatment. The appearance of high atrazine and alachlor concentrations with the first storm after application that produced leachate (Fig. 4) was consistent with other research reports on these chemicals (Kladivko et al., 1991; Edwards et al., 1992; Edwards et al., 1993). Both herbicides arrived in leachate samples at the same time, in spite of differences in adsorption coefficients that show alachlor to have greater soil sorption (Kladivko et al., 1991; Buhler et al., 1993). Leachate alachlor concentrations were usually about one-half that of atrazine, despite a higher application rate. The total herbicide recovered in leachate for 1993-1995 was about $1 \%$ of the applied atrazine, and approximately $0.4 \%$ of applied alachlor.

Table 5. Flow-weighted leachate atrazine as affected by spring manure and tillage.

\begin{tabular}{|c|c|c|c|c|c|c|c|c|c|c|c|c|c|}
\hline \multirow[b]{3}{*}{ Treatment $\dagger$} & \multicolumn{13}{|c|}{ Period $\$$} \\
\hline & \multicolumn{3}{|c|}{1993} & \multicolumn{4}{|c|}{1994} & \multicolumn{4}{|c|}{1995} & \multicolumn{2}{|c|}{1996} \\
\hline & 1 (Sp) & 2 (Su) & $3(\mathbf{F})$ & $4(W)$ & 5 (Sp) & $6(\mathrm{Su})$ & 7 (F) & $8(W)$ & 9 (Sp) & 10 (Su) & $11(\mathbf{F})$ & $12(W)$ & 13 (Sp) \\
\hline \multicolumn{14}{|c|}{ Spring manure by tillage trial (averaged over fertilizer $N$ treatments) } \\
\hline & & & & & & & atrazi & $\mathbf{L}^{-1}$ & 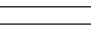 & & & & \\
\hline No manure & 42.6 & 1.4 & 1.4 & 0.7 & 41.7 & 1.5 & 0.6 & 0.7 & 56.2 & 4.7 & 2.4 & 5.1 & 1.2 \\
\hline Spring manure & 43.7 & 3.1 & 1.3 & 0.7 & 11.1 & 1.7 & 0.6 & 0.4 & 40.2 & 3.0 & 3.3 & 4.7 & 0.8 \\
\hline CD & 36.5 & 2.9 & 1.9 & 1.0 & 28.3 & 2.2 & 0.8 & 0.6 & 66.8 & 5.5 & 4.6 & 5.3 & 1.3 \\
\hline NT & 49.7 & 1.5 & 0.8 & 0.5 & 24.5 & 0.9 & 0.4 & 0.5 & 29.6 & 2.3 & 1.2 & 4.5 & 0.7 \\
\hline & \multicolumn{13}{|c|}{$p$ value $\S$} \\
\hline Manure & NS & 0.08 & NS & NS & 0.20 & NS & NS & 0.18 & 0.02 & 0.10 & NS & NS & 0.02 \\
\hline Tillage & NS & 0.15 & 0.14 & 0.06 & NS & 0.04 & 0.16 & NS & 0.01 & 0.01 & 0.11 & 0.24 & 0.01 \\
\hline Manure $\times$ tillage & 0.20 & 0.23 & NS & NS & NS & NS & NS & NS & 0.06 & 0.15 & NS & 0.05 & NS \\
\hline CV,$\%$ & 101 & 79 & 99 & 65 & 169 & 72 & 68 & 83 & 23 & 48 & 122 & 28 & 30 \\
\hline
\end{tabular}

$\dagger \mathrm{CD}=$ chisel/disk, NT $=$ no-tillage.

$\doteqdot \mathrm{Sp}=$ spring, $\mathrm{Su}=$ summer, $\mathbf{F}=$ fall, $\mathbf{W}=$ winter.

$\S$ Probability of observing an $F$ value at or above the sample test statistic. NS $=$ not significant at the $75 \%$ level of confidence. 
Table 6. Flow-weighted leachate alachlor as affected by spring manure and tillage.

\begin{tabular}{|c|c|c|c|c|c|c|c|c|c|c|c|c|c|}
\hline \multirow[b]{3}{*}{ Treatment $\dagger$} & \multicolumn{13}{|c|}{ Period $\$$} \\
\hline & \multicolumn{3}{|c|}{1993} & \multicolumn{4}{|c|}{1994} & \multicolumn{4}{|c|}{1995} & \multicolumn{2}{|c|}{1996} \\
\hline & $1(\mathbf{S p})$ & 2 (Su) & 3 (F) & $4(W)$ & $5(\mathrm{Sp})$ & $6(\mathrm{Su})$ & 7 (F) & $8(\mathbf{W})$ & 9 (Sp) & 10 (Su) & $11(\mathbf{F})$ & $12(W)$ & 13 (Sp) \\
\hline \multicolumn{14}{|c|}{ Spring manure by tillage trial (averaged over fertilizer $N$ treatments) } \\
\hline & & & & & & & alachl & $\mathbf{L}^{-1}$ & & & & & \\
\hline No manure & 56.4 & 0.7 & 0.3 & 0.2 & 21.6 & 1.0 & 0.3 & 0.3 & 29.4 & 2.6 & 1.2 & 3.5 & 0.2 \\
\hline Spring manure & 54.7 & 1.1 & 0.4 & 0.2 & 6.3 & 1.3 & 0.3 & 0.4 & 15.6 & 2.3 & 2.1 & 3.6 & 0.2 \\
\hline CD & 46.7 & 0.9 & 0.5 & 0.2 & 14.0 & 1.4 & 0.3 & 0.4 & 32.9 & 2.6 & 2.3 & 3.7 & 0.2 \\
\hline \multirow[t]{2}{*}{ NT } & 64.4 & 0.8 & 0.3 & 0.2 & 13.5 & 0.9 & 0.3 & 0.3 & 12.0 & 2.2 & 1.6 & 3.4 & 0.2 \\
\hline & \multicolumn{13}{|c|}{$p$ value } \\
\hline Manure & NS & 0.11 & NS & NS & 0.23 & 0.23 & NS & NS & 0.01 & NS & NS & NS & NS \\
\hline Tillage & NS & NS & 0.07 & NS & NS & 0.08 & NS & NS & 0.01 & NS & 0.16 & NS & NS \\
\hline Manure $\times$ tillage & 0.11 & NS & NS & NS & NS & 0.21 & NS & NS & 0.01 & NS & NS & 0.08 & NS \\
\hline CV, \% & 137 & 52 & 62 & 48 & 170 & 59 & 49 & 42 & 19 & 35 & 36 & 18 & 47 \\
\hline
\end{tabular}

$\dagger \mathrm{CD}=$ chisel/disk, NT $=$ no-tillage.

$+\mathbf{S p}=$ spring, $\mathbf{S u}=$ summer, $\mathbf{F}=$ fall, $\mathbf{W}=$ winter.

$\S$ Probability of observing an $F$ value at or above the sample test statistic. NS $=$ not significant at the $75 \%$ level of confidence.

Spring manure applications did significantly reduce flow-weighted atrazine and alachlor concentrations in the springs of 1994 and 1995, but had no significant effect in spring 1993 (Tables 5 and 6). Tillage had fairly consistent impacts on herbicide concentrations possibly because NT soils contain greater soil organic matter (SOM), as discussed below. Except for Period 1, use of NT usually resulted in lower atrazine and alachlor concentrations than did CD tillage (Tables 5 and 6). It should be noted, however, that leachate herbicide concentrations were less affected by tillage in the most important spring periods. The manure by tillage interaction was usually not statistically significant for either herbicide. Fertilizer $\mathrm{N}$ use, alone or in combination with other treatment factors, did not significantly affect concentrations of either herbicide in any period (data not shown).

We can speculate about several mechanisms, alone or in combination, by which manuring may have reduced herbicide leaching. Manure may have primed soil biological activity, which might have resulted in greater degradation of these herbicides in manured soil. The semisolid manure used in this study might have contributed to physical blocking of soil pores by surface crusting, which has been shown to reduced water infiltration rate in structured soils, giving time for greater sorption of herbicides to the soil matrix. Leachate volumes were often less under manured soils (Table 3). Manuring generally results in greater soil organic matter (SOM), and SOM can adsorb herbicides, changing the proportion of herbicide found in the soil solution of manured, relative to unmanured, soils. This latter mechanism is consistent with the observation that leachate herbicide concentrations were generally lower under NT soils, which usually possess greater SOM (Blevins et al., 1983). We did not measure SOM or herbicide degradation rates in our experimental area.

Shipitalo et al. (1990) observed that the first storm after herbicide application could move solutes into the soil matrix, thereby reducing the potential for transport in macropores in subsequent rainfall events. Kladivko et al. (1991) cited nonequilibrium sorption-desorption in soil pores as an explanation for the observed behavior of atrazine and alachlor transport through soil. Another possibility for the attenuation of the herbicides over time is that microbial degradation of these compounds occurred between rainfall events. Biochemical half-life estimates for atrazine and alachlor are 64 and $18 \mathrm{~d}$, respectively (Jury et al., 1987). Since alachlor is degraded more quickly, its concentrations would decrease more rapidly with subsequent drainage events than those for atrazine.

\section{CONCLUSIONS}

Tillage did not significantly affect leachate $\mathrm{NO}_{3}-\mathrm{N}$ during most periods in this experiment. The NT soils generally had higher $\mathrm{NO}_{3}-\mathrm{N}$ concentrations than did $\mathrm{CD}$ soils. Applying both fertilizer $\mathrm{N}$ and manure significantly increased $\mathrm{NO}_{3}-\mathrm{N}$ concentrations in leachate compared with the control treatments in most periods. Leachate $\mathrm{NO}_{3}-\mathrm{N}$, where only fertilizer at $168 \mathrm{~kg} \mathrm{~N}$ ha ${ }^{-1}$ was used, exceeded $10 \mathrm{mg} \mathrm{L}^{-1} 38 \%$ of the time, as compared with only $15 \%$ for the only spring manure application at a similar rate of available N. However, by the end of the study, leachate $\mathrm{NO}_{3}-\mathrm{N}$ under manured soils exceeded those where $\mathrm{N}$ fertilizer was used. This indicates that long-term manure use can have substantial positive impact, though delayed, on $\mathrm{NO}_{3}-\mathrm{N}$ leaching potential due to continued mineralization of $\mathrm{N}$ from accumulated manure-derived organic matter.

Tillage and manuring had opposite effects on leachate herbicide concentrations. The $\mathrm{CD}$ tillage generally raised leachate herbicide levels, while manuring generally lowered atrazine and alachlor in leachate. The timing and concentration of leachate herbicide suggest that their movement was dominated by macropore flow, with rainfall rapidly transmitting an initial amount of atrazine and alachlor through the soil matrix.

The substantial increase in leachate $\mathrm{NO}_{3}-\mathrm{N}$ that occurred where fertilizer was applied in conjunction with manure indicates that $\mathrm{N}$ fertilizer rates should be adjusted to compensate for $\mathrm{N}$ inputs from manure. Weather plays an important role in $\mathrm{N}$ management in cropping systems in Kentucky, due to relatively mild winter temperatures and abundant precipitation. Thus, to limit potential $\mathrm{N}$ leaching loss, manure and fertilizer $\mathrm{N}$ should be man- 
aged to keep post-harvest soil nitrate in the upper $90 \mathrm{~cm}$ of the soil profile less than $25 \mathrm{~kg} \mathrm{~N} \mathrm{ha}^{-1}$. From a farm management standpoint, this will be a challenge for a crop such as corn, which has a high $\mathrm{N}$ demand. Pang and Letey (2000) concluded that to satisfy the $\mathrm{N}$ demand of corn without synthetic fertilizers, large amounts of manure are required. This could leave much organic $\mathrm{N}$ available for subsequent mineralization and nitrate leaching.

A major goal of this study was to ascertain compatibility of no-till practices with manure use on well-drained soils. Spring manure had a significant effect on leachate $\mathrm{NO}_{3}-\mathrm{N}$ and herbicide concentrations, but the manure by tillage interaction did not. Therefore, the benefits and problems of manure use applied equally to both of the tillage systems used in this experiment. The results indicate that dairy manure can be utilized in a no-till corn system, but can also substantially impact vadosezone water quality (and, by inference, ground water) if the $\mathrm{N}$ mineralized from previous and present applications exceeds crop $\mathrm{N}$ requirements.

\section{ACKNOWLEDGMENTS}

The authors extend their appreciation for assistance with fieldwork by William Hare and Charles Stangle, and chemical analysis of manure and water by James Crutchfield and Tami Smith. Funding for this project was provided, in part, by a grant from the General Assembly of the Commonwealth of Kentucky-Senate Bill 271. The investigation reported in this paper (04-06-070) is in connection with a project of the Kentucky Agricultural Experiment Station and is published with the approval of the Director.

\section{REFERENCES}

Adams, P.L., T.C. Daniel, P.R. Edwards, D.J. Nichols, D.H. Pote, and H.D. Scott. 1994. Poultry litter and manure contributions to nitrate leaching through the vadose zone. Soil Sci. Soc. Am. J. 58:1206-1211.

Agri-Diagnostics Associates. 1992. Immunoassays: The future of analysis. Agri-Diagnostics Associates, Moorestown, NJ.

Angle, J.S., C.M. Gross, R.L. Hill, and M.S. McIntosh. 1993. Soil nitrate concentrations under corn as affected by tillage, manure, and fertilizer applications. J. Environ. Qual. 22:141-147.

Barrington, S.F., and C.A. Madramootoo. 1989. Investigating seal formation from manure infiltration into soils. Trans. ASAE 32: 851-856.

Blevins, R.L., J.H. Herbek, and W.W. Frye. 1990. Legume cover crops as a nitrogen source for no-till corn and grain sorghum. Agron. J. 82:769-772.

Blevins, R.L., M.S. Smith, G.W. Thomas, and W.W. Frye. 1983. Influence of conservation tillage on soil properties. J. Soil Water Conserv. 38:301-305.

Bottom, J.D., J.L. Taraba, and I.J. Ross. 1986. Infiltration rate reduction on dairy manured plots. ASAE Paper 86-4057. ASAE, St. Joseph, MI.

Buhler, D.D., G.W. Randall, W.C. Koskinen, and D.L. Wyse. 1993. Atrazine and alachlor losses from subsurface tile drainage of a clay loam soil. J. Environ. Qual. 22:583-588.

Carmer, S.G., and W.M. Walker. 1988. Significance from a statistician's viewpoint. J. Prod. Agric. 1:27-33.

Clanton, C.J., and D.C. Slack. 1987. Hydraulic properties of soils as affected by surface application of wastewater. Trans. ASAE 30:683687.

Das, D.K., and K.J. Chaudhri. 1981. Infiltration and redistribution of soil water as influenced by crust formation, cultivation, and farmyard manure application. J. Indian Soc. Soil Sci. 29:543-546.
Doran, J.W. 1980. Soil microbial and biochemical changes associated with reduced tillage. Soil Sci. Soc. Am. J. 44:765-771.

Edwards, W.M., M.J. Shipitalo, W.A. Dick, and L.B. Owens. 1992. Rainfall intensity affects transport of water and chemicals through macropores in no-till soil. Soil Sci. Soc. Am. J. 56:52-58.

Edwards, W.M., M.J. Shipitalo, L.B. Owens, and W.A. Dick. 1993. Factors affecting preferential flow of water and atrazine through earthworm burrows under continuous no-till corn. J. Environ. Qual. 22:453-457.

Edwards, W.M., M.J. Shipitalo, L.B. Owens, and L.D. Norton. 1989. Water and nitrate movement in earthworm burrows within longterm no-till cornfields. J. Soil Water Conserv. 44:240-243.

Eghball, B., and J.F. Power. 1999. Composted and noncomposted manure application to conventional and no-tillage systems: Corn yield and nitrogen uptake. Agron. J. 91:819-825.

Freese, R.C., D.K. Cassel, and H.P. Denton. 1993. Infiltration in a Piedmont soil under three tillage systems. J. Soil Water Conserv. 48:214-218.

Jemison, J.M., and R.H. Fox. 1994. Nitrate leaching from nitrogenfertilized and manured corn measured with zero-tension pan lysimeters. J. Environ. Qual. 23:337-343.

Jokela, W.E. 1992. Nitrogen fertilizer and dairy manure effects on corn yield and soil nitrate. Soil Sci. Soc. Am. J. 56:148-154.

Jury, W.A., D.D. Focht, and W.J. Farmer. 1987. Evaluation of pesticide groundwater pollution potential from standard indices of soilchemical adsorption and biodegradation. J. Environ. Qual. 16: 422-428.

Keeney, D.R., and D.W. Nelson. 1982. Nitrogen: Inorganic forms. p. 643-698. In A.L. Page, R.H. Miller, and D.R. Keeney (ed.) Methods of soil analysis. Part 2. 2nd ed. Agron. Monogr. 9. ASA and SSSA, Madison, WI.

Kladivko, E.J., G.E. VanScoyoc, E.J. Monke, K.M. Oates, and W. Pask. 1991. Pesticide and nutrient movement into subsurface tile drains on a silt loam soil in Indiana. J. Environ. Qual. 20:264-270.

Ma, B.L., L.M. Dwyer, and E.G. Gregorich. 1999. Soil nitrogen amendment effects on seasonal nitrogen mineralization and nitrogen cycling in maize production. Agron. J. 91:1003-1009.

MacDonald, A.J., D.S. Powlson, P.R. Poulton, and D.S. Jenkinson. 1989. Unused fertilizer nitrogen in arable soils-Its contribution to nitrate leaching. J. Sci. Food Agric. 46:407-419.

McMahon, M.A., and G.W. Thomas. 1976. Anion leaching in two Kentucky soils under conventional tillage and a killed-sod mulch. Agron. J. 68:437-442.

Munyankusi, E., S.C. Gupta, F.F. Moncreif, and E.C. Berry. 1994. Earthworm macropores and preferential transport in a long-term manure applied Typic Hapludalf. J. Environ. Qual. 23:773-784.

Pang, X.P., and J. Letey. 2000. Organic farming: Challenge of timing nitrogen availability to crop nitrogen requirements. Soil Sci. Soc. Am. J. 64:247-253.

Roth, G.W., and R.H. Fox. 1990. Soil nitrate accumulations following nitrogen-fertilized corn in Pennsylvania. J. Environ. Qual. 19:243-248.

SAS Institute. 1989. SAS user's guide: Statistics. Version 6. SAS Inst., Cary, NC.

Shipitalo, M.J., and W.M. Edwards. 1993. Seasonal patterns of water and chemical movement in tilled and no-till column lysimeters. Soil Sci. Soc. Am. J. 57:218-223.

Shipitalo, M.J., W.M. Edwards, W.A. Dick, and L.B. Owens. 1990. Initial storm effects on macropore transport of surface-applied chemicals in no-till soil. Soil Sci. Soc. Am. J. 54:1530-1536.

Shipitalo, M.J., W.M. Edwards, and C.E. Redmond. 1994. Comparison of water movement in earthworm burrows and pan lysimeters. J. Environ. Qual. 23:1345-1351.

Sims, J.T. 1987. Agronomic evaluation of poultry manure as a nitrogen source for conventional and no-tillage corn. Agron. J. 79:563-570.

Stoddard, C.S., M.S. Coyne, and J.H. Grove. 1998. Fecal bacteria survival and infiltration through a shallow agricultural soil: Timing and tillage effects. J. Environ. Qual. 27:1516-1523.

Thomas, G.W., and R.E. Phillips. 1979. Consequences of water movement in macropores. J. Environ. Qual. 8:149-152.

Tyler, D.D., and G.W. Thomas. 1977. Lysimeter measurements of nitrate and chloride losses from soil under conventional and notillage corn. J. Environ. Qual. 6:63-66. 